\title{
IMPORTANCE OF ASSISTED REPRODUCTIVE TECHNOLOGIES IN THE CONSERVATION OF WILD, RARE OR INDIGENOUS UNGULATES: REVIEW ARTICLE
}

\author{
S. CSEH ${ }^{*}$ and L. SOLTI \\ Department and Clinic of Animal Reproduction, Faculty of Veterinary Science, \\ Szent István University, H-1400 Budapest, P.O. Box 2, Hungary
}

(Received January 3, 2000; accepted May 3, 2000)

\begin{abstract}
Biodiversity is increasingly threatened by intensive agriculture, environmental pollution, extinction of natural habitats and several other factors. Several mammalian species including ungulates have disappeared or are threatened by extinction. However, ungulates play an important role both in the ecosystem and in the economy. In general, species or breeds are considered endangered if their population does not exceed 1,000 individuals. In these cases conservation programmes should be initiated in order to maintain or even increase their number. This review deals with the possibilities and limitations of assisted reproductive technologies (ART) in the conservation of ecologically valuable wild, rare and indigenous ungulates. The methods discussed here are artificial insemination, cryopreservation of semen and embryos, embryo recovery and transfer, in vitro production of embryos, as well as micromanipulation techniques including sperm injection, assisted hatching and cloning. Some of these procedures are already being exploited in the breeding of farm ungulates, but more basic information about the reproductive patterns of wild, rare and indigenous animal species is needed before the routine use of ARTs.
\end{abstract}

Key words: Rare and endangered ungulates, assisted reproductive technologies, conservation programs

In many countries the development of agricultural technologies and the spread of intensive production systems including breeding programmes and forest management have resulted in serious changes in rare or ecologically valuable species. In the past two centuries 46 mammalian species have disappeared and many others are endangered, having a population size below 1,000 individuals (Loskutoff et al., 1995). However, due to their cultural, historical and genetic importance, attempts are being made to conserve genomes and/or individual genes by employing biotechnological and/or assisted reproductive technologies (ART). The conservation would allow, if required, reactivation in their original form that might have become extinct. It has been demonstrated that genetic ho-

*E-mail: scseh@univet.hu; Fax: +36 (1) 3943959 
mogenization has negative effects on domestic and wild animal species, such as increased juvenile mortality, poor reproductive performance, and susceptibility to disease (Brem et al., 1989; Lasley et al., 1994). In situ conservation of threatened animals means a population saved and kept in national parks; they are visible and not to be forgotten but very susceptible to infectious or other lethal diseases. Ex situ conservation is a stock of genetic material (semen, embryos or ova) deep frozen in liquid nitrogen which is relatively safe and inexpensive, but over decades the physical appearance of the animals can be forgotten by the public. Biotechnology and ART have clear benefits for conservation biology and are very promising in the preservation of both the ecologically valuable, wild, rare and indigenous species and the genetic variability within such species (Raven et al., 1992; Lasley et al., 1994; Loskutoff et al., 1995; Loskutoff and Betteridge, 1993; Solti et al., 2000). ART have been widely and successfully used in both humans and domestic animals for many years. However, the application of such technologies in less or nondomesticated, native, rare or endangered animals proves to be very difficult. It still remains to be demonstrated that biotechnology and ART can be used routinely to actually conserve a rare or endangered species.

Among domestic animals, ungulates play an important economic role. However, intensive breeding of high-yielding farm animals seemed to make indigenous breeds dispensable for owners. In fact, indigenous breeds may possess several advantageous qualities (resistance to diseases, endurance, solid hoof structure, low nutritional demand, etc.) that must not become extinct in the future. Recently, attention has been paid to milk protein genetic variants with special regard to $\kappa$-casein gene of indigenous bovine breeds like Barrosa and Hungarian Grey (Baranyi et al., 1993; Bastos et al., 1999). These genes may be of economic importance for increasing the quality of milk for cheese production. Another example for this in Hungary is the change from the dominant traditional dual-purpose cattle breed to the high-yielding dairy Holstein-Friesian. Although this change has significantly increased the national milk production, the meat quality of the Holstein is inferior to that of dual-purpose or beef breeds, thus the ancient breeds should partly be re-introduced. Another example is the indigenous Mangalica swine which, compared to Landrace-type pigs, has a slower growth rate and significantly more fat and, therefore, almost became extinct in the last decades. Today it is bred again for valuable food products such as dried ham and salami.

For this overview, biotechnology and ART are considered as procedures used to conserve and/or assist the reproduction of ungulates. The methods discussed here range from practical, applied techniques [e.g. artificial insemination (AI), embryo transfer (ET)] to more complex methods [e.g. in vitro fertilisation (IVF), in vitro production of embryos (IVP), gamete or embryo micromanipulation]. Each of these techniques has been used to assist mammalian reproduction and improve the genetic diversity and reproductive efficiency of domestic livestock. 


\section{Artificial insemination}

Artificial insemination (AI) is the most widely applied ART. Offspring have been produced by AI in different animal species and in man (for a review see Wildt, 1991 and Wildt et al., 1992a). The experiences obtained in farm animals have demonstrated the value of AI combined with semen cryopreservation (CP). AI and semen CP can maximise the reproductive potential of valuable males, without limitations of time and distance. Moreover, genetic material of males can be preserved for a long time without taking up space in zoos or farms, thus genetic goals can be achieved even for small populations. Using a computer simulation model, Johnston and Lacy (1991) demonstrated that maximum genetic diversity can be maintained in a small gaur herd with as few as 40 individuals by AI combined with semen CP. Currently, frozen semen is being stored from 41 animal species, 15 of which no longer live. To date, AI with frozenthawed sperm resulted in offspring from 28 mammalian species, 16 of which can be classified as nondomesticated (Wildt et al., 1992a; Wildt et al., 1992b).

Interest in applying AI to ecologically valuable wild, rare and indigenous ungulates has been preceded by comparative investigations of cattle and sheep. The results indicate that the efficiency of AI depends on the precise timing of insemination determined by the time of ovulation. Correct timing of AI can be achieved either by accurate identification of animals in natural heat or by using fixed-time AI of synchronised animals. Oestrus synchronisation has widely been used in domestic ungulates for 20 years. Standard synchronisation procedures developed for cattle (e.g. PGF $_{2 \alpha}$, norgestomet) and sheep (e.g. MAP-pessaries, CIDR intravaginal devices) have been used with acceptable success in nondomestic ungulates. However, the actual time of ovulation has been very difficult to assess, thus the routine use of AI and ET in these animals is quite limited (Schiewe et al., 1991; Wildt et al., 1992a). Unfortunately, behavioural cues are not reliable indicators for detecting oestrus in these animals. Measurement of blood hormone concentrations for this purpose can be confounded by the effects of physical restraint or anaesthesia that are often necessary for blood collection. Alternatively, methods for monitoring the ovarian cycle, characterising the endocrine patterns of the oestrous cycle and diagnosing reproductive failures have been performed using urine and/or faecal samples in nondomestic species (Loskutoff et al., 1983; Lasley and Kirkpatrick, 1991).

Noninvasive techniques of vaginal or transcervical semen application are generally ineffective in large nondomestic ungulates, particularly with frozen semen (Lasley et al., 1994). The pregnancy rate was higher when the semen was deposited directly into the uterine horn using a laparoscopic technique (Asher et al., 1990; Wildt et al., 1992a; Wildt et al., 1992b). Laparoscopic insemination is an alternative route involving direct deposition of very small quantities of semen into the uterine horns following visualisation of the abdominal and pelvic organs. 
This technique, developed in ewes, has been used successfully with excellent conception rates in Hungarian Mangalica swine, fallow deer and red deer (Asher et al., 1988; Asher et al., 1990; Fenessy et al., 1990; Rátky et al., 2000, accepted for publication). Much research has been conducted in cervids on oestrus synchronisation and semen collection and conservation as well (Monfort et al., 1990; Garde et al., 1998).

\section{Embryo transfer}

\section{Ovarian stimulation}

Superovulation using cattle and sheep protocols has been performed on nondomestic ungulates such as antelopes, giraffe, deer, wild cattle, buffalo, camelids and bison (Elsden et al., 1978; Stover et al., 1981; Seidel and Seidel, 1981; Dresser et al., 1984; Dresser et al., 1985; Karaivanov, 1986; Pope et al., 1988; Loskutoff et al., 1988; Loskutoff et al., 1990; Dixon et al., 1991; Schiewe et al., 1991; Fenessy et al., 1994; McKinnon et al., 1994; Dorn, 1995; Del Campo et al., 1995). Ovarian response to traditional stimulation protocols in nondomestic ungulates is quite inconsistent. The limited success may be related, in part, to species resilience to the exogenous gonadotropins as well as to stress provoked by repeated restraining for treatments (Schiewe et al., 1991). In addition, the use of exogenous gonadotropins may cause the formation of antibodies and abnormal corpora lutea. Abnormal corpora lutea cause early luteal regression and loss of embryos (Loskutoff et al., 1990). However, recent progress provides encouraging evidence that bovine and ovine superovulatory protocols can be adapted successfully to nondomestic ungulates like deer (Dixon et al., 1991; Fenessy et al., 1994; Garde et al., 1998).

\section{Embryo recovery and transfer}

The nonsurgical bovine embryo recovery method is effective in most large ungulate species where per rectum palpation is possible, except in giraffe and okapi in which the cervices are impenetrable (Dresser et al., 1984; Dresser et al., 1985; Loskutoff et al., 1988; Schiewe et al., 1991a; Fenessy et al., 1994). The laparoscopic technique developed for sheep and goats could be a very valuable procedure to retrieve embryos in small ungulates (Kraemer, 1989; Loskutoff et al., 1991; Besenfelder et al., 1994; Kuhholzer et al., 1997).

Nonsurgical ET through the cervix has also been possible in the large antelope, wild cattle, buffalo and camelid species. Birth of live offspring following transcervical ET has been achieved in the eland, bongo, oryx, gaur, dromedary camel and llama (Dresser et al., 1984; Dresser et al., 1985; Pope et al., 1988; Pope et al., 1991; McKinnon et al., 1994; Del Campo et al., 1995). Transabdominal laparoscopic ET technique developed on sheep has been successfully 
applied to the suni antelope (Schiewe et al., 1984; Kraemer, 1989; Loskutoff et al., 1990).

In some species in which the number of available individuals is very limited, interspecies ET might be the only choice to keep acceptable genetic variability within the population and in this way to avoid inbreeding. Successful interspecies ETs have been performed from gaur to domestic Holstein cattle, from exotic wild horses to domestic ones, from Indian desert cat to domestic strains (from wild cats to domestic ones), from bongo antelope to eland (Stover et al., 1981; Dresser et al., 1985; Summers et al., 1987; Pope et al., 1989). However, interspecies ET is frequently accompanied by side effects like early resorption and late abortion, malformations, reduced number of placentomes, abnormal histological development, etc. (Stover et al., 1981; Summers et al., 1987; Hradecky et al., 1988; Buckrell et al., 1990).

\section{In vitro embryo production (IVP)}

In vitro embryo production (in vitro maturation, fertilisation and culture; IVM, IVF, IVC; IVMFC) offers several advantages over the collection of in vivo derived embryos including: (1) circumvention of the problem of timing ovulation for AI; (2) the potential for producing more embryos than can usually be collected from hormonally-stimulated donors; (3) the ability to use animals with certain types of infertility, such as endometritis or tubal obstruction; (4) a reduction in the number of viable spermatozoa as compared to AI or natural breeding; (5) using sperm microinjection techniques, the potential of using nonmotile or nonviable sperm and testicular- or epididymal-derived sperm for assisted fertilisation; (6) the potential of salvaging genetic material from female animals after death; and (7) the possible inclusion of prepuberal or pregnant animals as oocyte donors (Loskutoff et al., 1995).

Although offspring have been produced from in vitro produced embryos in a variety of ungulates, primates and carnivores, the IVM of immature oocytes proves to be very difficult in certain species such as felids and equids (Loskutoff and Betteridge, 1993; Li et al., 1994; Gordon, 1994; Lasley et al., 1994; Meintjes et al., 1994; Meintjes et al., 1995; Pope et al., 1995). Recently, an Indian gaur calf has been obtained after in vitro maturation, fertilisation and culture of an oocyte (Johnston et al., 1993). Elephant oocytes may be capable to undergo maturation in vitro, however this ability of elephant oocytes depends upon the age and parity of the oocyte donor (Christensen et al., 1993).

Transvaginal ultrasound-guided oocyte retrieval has been proven to be safe and efficient for collecting oocytes from cows, mares, and goats as well as from pregnant cows and mares (Pieterse et al., 1988; Gordon, 1994; Meintjes et al., 1994; Meintjes et al., 1995). These ovum pick up procedures have been suc- 
cessfully applied, with minor modification, to different nondomestic zoo ungulates housed in captivity (Meintjes et al., 1994; Meintjes et al., 1995; Loskutoff et al., 1995; Armstrong et al., 1995). In the future, an alternative technique could be laparoscopy developed for the repeated aspiration of bovine follicular oocytes (Reichenbach et al., 1994).

Sperm quality and in vitro sperm capacitation are the most important factors determining the success of in vitro embryo production (Bárándi et al., 1993). Embryos have been recently produced from IVM-IVF oocytes in domestic horses ( $\mathrm{Li}$ et al., 1994; Meintjes et al., 1994). In certain species (Burchell's zebra stallion) and circumstances (epididymal sperm) the successful induction of acrosome reaction and capacitation are limiting factors of IVM-IVF (Schiewe et al., 1984). An alternative to cryopreserving ejaculatory semen may be the direct refrigeration of testicles and freezing of epididymal sperm (Bezuidenhout et al., 1995). Ejaculated semen can be routinely collected and frozen in domestic and nondomestic ungulate species; however, optimal cryoprotective extenders are species dependent (Howard et al., 1986; Schiewe, 1991; Schiewe et al., 1991a, 1991b).

Procedures used for IVC of embryos have been developed in humans, nonhuman primates, laboratory or domestic animals. However, the results indicate differences in the requirements for embryo development in vitro even between closely related species. Culture methods for bovine embryos appear to be effective to ensure embryo development to the blastocyst stage in wild cattle, water buffalo, giraffe and South American camelids, as well as in certain antelope species such as the greater kudu and impala (Johnston et al., 1993; Monfort et al., 1993; Del Campo et al., 1995; Loskutoff et al., 1995). However, using the same procedure no embryo development beyond the morula stage can be obtained in the African buffalo (Shaw et al., 1995). It has been shown that IVP ungulate embryos can be successfully cryopreserved but they are more sensitive to low temperature (Leibo and Loskutoff, 1993; Cseh et al., 1995). IVF has been used successfully for embryo production from the endangered Hungarian Grey cattle breed (Solti et al., 1992).

\section{Gamete and embryo micromanipulation}

Micromanipulation has become increasingly common in mammalian embryology. Bovine proteins have been injected into mouse embryos, two-cell mouse embryos were separated into constituent blastomeres, tissue was excised from rabbit blastocysts for genetic typing, a donor cell was injected into the blastocoelic cavity of mouse blastocysts, and cloning (even from somatic cells) began in mammals (Wilmut et al., 1997). Recently, adult somatic cell nucleus transfer was used successfully to preserve the last surviving cow of the Enderby 
Island cattle breed. The technology may be used to propagate other endangered indigenous breeds in the future (Wells et al., 1999).

Pioneering fertilisation experiments concerning with microinjection of hamster and human sperm into the cytoplasm of hamster oocytes led to the development of a clinical application called 'assisted fertilisation' (Uehara and Yanagimachi, 1976). Three micromanipulative methods of assisting fertilisation are already in practice (Edwards and Brody, 1995). The first involves making small holes or slits in the zona pellucida by methods known as zona drilling, cracking, or cutting, or by using acidified medium or a sharp glass needle permitting weakly motile spermatozoa to gain access to the oolemma (Loskutoff et al., 1993; Edwards and Brody, 1995). Second, one or more spermatozoa are inserted into the perivitelline space (subzonal insemination, SUZI; Mann, 1988). Third, a spermatozoa or sperm head is injected directly into the ooplasm called intracytoplasmic sperm injection (ICSI; Kimura and Yanagimachi, 1995; Edwards and Brody, 1995). More recently, the development of ICSI has resulted in a marked increase in the fertilisation rates achieved by microinjection as well as in improved pregnancy rates after transfer. A fourth method has been added recently when a spermatid or spermatocyte nucleus was injected into the oocyte (Kimura and Yanagimachi, 1995).

The importance of ICSI to wildlife or rare animal preservation appears limitless, as even testicular-and epididymal-derived or freeze-dried spermatozoa are capable of decondensing in the ooplasm and producing viable embryos and offspring (Kimura and Yanagimachi, 1995; Wakayama and Yanagimachi, 1998). ICSI of nonviable sperm has even resulted in the birth of live calves (Goto et al., 1991). However, the results of sperm injection indicate that the procedure may be species specific. Results indicate that for cat and mouse oocytes ICSI is less effective than SUZI which produced embryos capable of full-term development (Mann, 1988; Pope et al., 1995; Yanagimachi, 1998). The different procedures used for sperm insertion will have an important role to play in future conservation efforts, particularly for endangered species in which males have a high proportion of abnormal sperm and/or no method available for successful IVF or cryopreservation of sperm (Gordon and Talansky, 1986; Monfort et al., 1993; Li et al., 1994; Meintjes et al., 1994; Burruel et al., 1996; Wakayama and Yanagimachi, 1998).

Treatments on embryos such as zona drilling or partial zona dissection could raise their chances of implantation (Gordon and Talansky, 1986; Edwards and Brody, 1995). Drilling holes on the zona pellucida might facilitate embryos to hatch earlier from the zona pellucida hardened by ovarian stimulation and/or embryo culture. Results obtained by Loskutoff et al. (1993) indicate that partial zona dissection improves the hatching frequencies of CP bovine blastocysts produced in vitro and co-culture conditions can affect survival after thawing. It is probable that IVP wildlife, rare and indigenous animal embryos will also benefit from assisted hatching techniques. 


\section{References}

Armstrong, D., Looney, C., Lindsey, B., Gonseth, C., Johnson, D., Williams, K., Simmons, L. and Loskutoff, N. M. (1995): Transvaginal egg retrieval and in vitro embryo production in gaur (Bos gaurus) with establishment of interspecies pregnancy. Theriogenology 43, 162.

Asher, W., Kraemer, D., Magyar, S., Brunner, M., Moerbe, R. and Giaquinto, M. (1990): Intrauterine insemination of farmed fallow deer (Dama dama) with frozen-thawed semen via laparoscopy. Theriogenology 34, 569-578.

Asher, W., Adams, L., James, W. and Barnes, D. (1988): Artificial insemination of farmed fallow deer (Dama dama): Fixed-time insemination at a synchronized oestrus. Anim. Prod. 47, 487-492.

Bárándi, Zs., Solti, L., Cseh, S., Varga, Zs., Macháty, Z. and Vajta, G. (1993): Comparison of the in vitro fertilizing ability of sperm from endangered Hungarian Grey bulls. Animal Reprod. Sci. 31, 13-19.

Baranyi, M., Bősze, Zs., Buchberger, J. and Krause, I. (1993): Genetic polymorphism of milk protein in Hungarian Spotted and Hungarian Grey Cattle: a possible new genetic variant of $\beta$ Lactoglobulin. J. Dairy Sci. 76, 630-636.

Bastos, E., Varejao, M., Chaves, R., Cravador, A., Alves, V. and Guedes-Pinto, H. (1999): Genetic polymorphism of $\kappa$-casein gene in Barrosa Portuguese indigenous bovine breed. European Congress on Biotechnology, ECB9/2482. Brussels.

Besenfelder, U., Zinovieva, N., Dietrich, E., Solinrey, B., Holtz, W. and Brem, G. (1994): Tubal transfer of goat embryos using endoscopy. Vet. Rec. 135, 480-485.

Bezuidenhout, C., Fourie, F., Meintjes, M., Bornman, M., Bartels, P. and Godke, R. (1995): Comparative epididymal sperm cell motility of African ungulate and equid game species stored at $4{ }^{\circ} \mathrm{C}$. Theriogenology $43,167$.

Brem, G., Brenig, B., Muller, M. and Springmann, K. (1989): Ex situ cryoconservation of genomes and genes of endangered cattle breeds by means of modern biotechnological methods. FAO Animal Production and Health Paper (76), Rome.

Buckrell, B., Gartley, C., Mehren, K., Crawshaw, G., Johnson, W., Barker, K., Balke, J., Coghill, C., Challis, J. and Goodrowe, K. (1990): Failure to maintain interspecific pregnancy after transfer of Dall's sheep embryos to domestic ewes. J. Reprod. Fert. 90, 387-394.

Burruel, V., Yanagimachi, R. and Whitten, W. (1996): Normal mice develop from oocytes injected with spermatozoa with grossly misshapen heads. Biol. Reprod. 55, 709-717.

Christensen, M., Schmidt, M., Hess, D. and Alak, B. (1993): Oocyte nuclear maturation in vitro in the African (Loxodonta africana) and Asian elephant (Elephas maximus). Biol. Reprod. 48 (Suppl. 1), 88-95.

Cseh, S., Kreysing, U., Lucas-Hahn, A. and Niemann, H. (1995): Direct rehydration of IVF bovine embryos frozen in ethylene-glycol. Theriogenology 43, 190.

Del Campo, M., Del Campo, C., Adams, G. and Mapletoft, R. (1995): The application of new technologies to South American camelids. Theriogenology 43, 21-30.

Dixon, E., Hunter, J. and Beatson, N. (1991): Pregnancies following the export of frozen red deer embryos from New Zealand to Australia. Theriogenology 35, 193.

Dorn, C. (1995): Reproductive applications in the American bison (Bison bison). Theriogenology 43, 13-20.

Dresser, B., Kramer, L. and Dalhausen, R. (1984): Cryopreservation followed by successful transfer of African eland antelope (Taurotragus oryx) embryos. Proc. 10th Int. Congr. Animal Reprod. AI 2, 191.

Dresser, B., Pope, C., Kramer, L., Kuehn, G., Dalhausen, R., Maruska, E., Reece, B. and Thomas, W. (1985): Birth of bongo antelope (Tragelaphus euryceros) to eland antelope (Tragelaphus oryx) and cryopreservation of bongo embryos. Theriogenology 23, 190. 
Edwards, R. and Brody, S. (1995): Principles and Practice of Assisted Human Reproduction. W. B. Saunders Company, Philadelphia.

Elsden, R., Nelson, L. and Seidel, G. (1978): Superovulating cows with follicle stimulating hormone and pregnant mares' serum gonadotropin. Theriogenology 9, 17-26.

Fenessy, P., Asher, G., Beatson, N., Dixson, E., Hunter, J. and Bringans, M. (1994): Embryo transfer in deer. Theriogenology 41, 133-138.

Fenessy, P., Mackintosh, C. and Skackell, G. (1990): Artificial insemination of farmed red deer (Cervus elaphus). Anim. Prod. 51, 613-621.

Garde, J., Landete-Castillejos, T. and Lopez-Saez, A. (1998): Reproductive technologies for nondomestic species and wildlife preservation. AETE Newsletter No. 9, 9-15.

Gordon, I. (1994): Laboratory Production of Cattle Embryos. CAB Int., Wallingford.

Gordon, J. and Talansky, B. (1986): Assisted fertilization by zona drilling: A mouse model for correction of oligospermia. J. Exp. Zool. 239, 347-354.

Goto, K., Kinoshita, A., Takuma, Y. and Ogawa, K. (1991): Birth of calves after the transfers of oocytes fertilized by sperm injection. Theriogenology 35, 205-221.

Howard, J., Bush, M., de Vos, V., Schiewe, M., Pursel, V. and Wildt, D. (1986): Influence of cryoprotective diluent on post-thaw viability and acrosomal integrity of spermatozoa of the African elephant (Loxodonta africana). J. Reprod. Fertil. 78, 295-306.

Hradecky, P., Stover, J. and Stott, G. (1988): Histology of a heifer placentome after interspecies transfer of gaur embryo. Theriogenology 30, 593-604.

Johnston, L. and Lacy, R. (1991): Utilization of sperm banks to maintain genetic diversity in captive populations of wild cattle. Proc. Wild Cattle Symposium, New York, pp. 107-118.

Johnston, L., Parrish, J., Monson, R., Leibfried-Rutledge, L., Susko-Parrish, J., Northey, D., Rutledge, J. and Simmons, L. (1993): Oocyte maturation, fertilization and embryo development in vitro and in vivo in the gaur (Bos gaurus). J. Reprod. Fertil. 100, 131-136.

Karaivanov, C. (1986): Comparative studies on the superovulatory effect of PMSG and FSH in water buffalo (Bubalus bubalis). Theriogenology 26, 51-56.

Kimura, Y. and Yanagimachi, R. (1995): Mouse oocytes injected with testicular spermatozoa or round spermatids can develop into normal offspring. Development 121, 2397-2405.

Kraemer, D. (1989): Embryo collection in small ruminants. Theriogenology 31, 141-148.

Kuhholzer, B., Muller, S., Besenfelder, U. and Brem, G. (1997): Endoscopic embryo transfer techniques in sheep. 3. Intrauterine insemination and tubal transfer of embryos. Wiener Tierärztl. Mschr. 84, 14-19.

Lasley, B. and Kirkpatrick, J. (1991): Monitoring ovarian function in captive and free-ranging wildlife by means of urinary and fecal steroids. J. Zoo Wildlife. Med. 22, 23-31.

Lasley, B., Loskutoff, N. M. and Anderson, B. (1994): The limitation of conventional breeding programs and the need and promise of assisted reproduction in nondomestic species. Theriogenology 41, 119-132.

Leibo, S. and Loskutoff, N. M. (1993): Cryobiology of in vitro derived bovine embryos. Theriogenology 39, 81-94.

Li, L., Meintjes, M., Graff, K., Paul, J., Denniston, R. and Godke, R. (1994): In vitro fertilization and development of in vitro matured oocytes aspirated from pregnant mares. Proc. 6th Int. Symp. Equine Reprod. pp. 77-78.

Loskutoff, N. M., Bartels, P., Meintjes, M., Godke, R. and Schiewe, M. C. (1995): Assisted reproductive technology in nondomestic ungulates: a model approach to preserving and managing genetic diversity. Theriogenology 43, 3-12.

Loskutoff, N. M. and Betteridge, K. (1993): Embryo technology in pets and endangered species. In: Lauria, A. and Gandolfi, F. (eds) Embryonic Development and Manipulation in Animal Production: Trends in Research and Application. Portland Press, London, pp. 235-248.

Loskutoff, N. M., Greve, T., Betteridge, K. and Leibo, S. (1993): Co-culture conditions and partial zona dissection affect hatching rates of thawed bovine blastocysts produced in vitro. Theriogenology 39, 263. 
Loskutoff, N. M., Ott, J. and Lasley, B. (1983): Strategies for assessing ovarian function in exotic species. J. Zoo Animal Med. 14, 3-12.

Loskutoff, N. M., Raphael, B., Dorn, C., Nemec, L., Calle, P., Petric, A. and Kraemer, D. (1988): Comparative reproductive traits of the okapi and giraffe: Implications for intraspecific and intergeneric embryo transfer. Acta Zool. Path. Antverpiensia 80, 29-42.

Loskutoff, N. M., Raphael, B., Nemec, L., Wolfe, B., Howard, J. and Kraemer, D. (1990): Reproductive anatomy, manipulation of ovarian activity and non-surgical embryo recovery in suni (Neotragus moschatus yuluensis). J. Reprod. Fertil. 88, 521-532.

Loskutoff, N. M., Raphael, B., Wolfe, B., French, L., Buice, R., Howard, J., Schiewe, M. and Kraemer, D. (1991): Embryo transfer in small antelope. Proc. Soc. Study Theriogenology. pp. 341-342.

Madan, M., Singla, S., Chauhan, M. and Manik, R. (1994): In vitro production and transfer of embryos in buffaloes. Theriogenology 41, 139-144.

Mann, J. (1988): Full term development of mouse eggs fertilized by a spermatozoa microinjected under the zona pellucida. Biol. Reprod. 38, 1077-1084.

McKinnon, A., Tinson, A. and Nation, G. (1994): Embryo transfer in dromedary camels. Theriogenology 41, 145-150.

Meintjes, M., Bartels, P., Bezuidenhout, C., Visser, D., Meintjes, J., Loskutoff, N. M., Barry, D., Fourie, F. and Godke, R. (1995): In vitro fertilization of in vitro matured oocytes recovered from free-ranging zebra in South-Africa. Theriogenology 43, 279.

Meintjes, M., Bellow, M., Paul, J., Broussard, J., Li, L., Paccamonti, D., Eilts, B. and Godke, R. (1994): Transvaginal ultrasound-guided oocyte retrieval in cyclic and pregnant horse and pony mares for in vitro fertilization. Proc. 6th Int. Symp. Equine Reprod. pp. 71-72.

Monfort, L., Asher, W., Wildt, E., Wood, C., Schiewe, C., Williamson, R., Bush, M. and Rall, F. (1993): Successful intrauterine insemination in Eld's deer (Cervus eldi thamin) using frozen-thawed spermatozoa. J. Reprod. Fertil. 99, 459-465.

Monfort, L., Wemmer, C., Kepler, T., Bush, M., Brown, J. and Wildt, E. (1990): Monitoring ovarian function and pregnancy in the Eld's deer (Cervus eldi thamin) by evaluating urinary steroid metabolite excretion. J. Reprod. Fertil. 88, 271-281.

Pieterse, M., Kappen, K., Kruip, T. and Taverne, M. (1988): Aspiration of bovine oocytes during transvaginal ultrasound scanning of the ovaries. Theriogenology 30, 751-762.

Pope, C., Dresser, B., Kuehn, G., Kramer, L. and Gillespie, D. (1988): Live birth of a gaur (Bos gaurus) calf following nonsurgical embryo transfer to a Holstein (Bos taurus) recipient. Theriogenology 29, 289.

Pope, C., Gelwicks, E., Burton, M., Reece, R. and Dresser, B. (1991): Nonsurgical embryo transfer in the scimitar-horned oryx (Oryx dammah): Birth of a live offspring. Zoo Biol. 10, 43-51.

Pope, G., Gelwicks, E., Wachs, K., Keller, G., Maruska, E. and Dresser, B. (1989): Successful interspecies transfer of embryos from the Indian desert cat (Felis silvestris ornata) to the domestic cat (Felis catus). Biol. Reprod. 40, 61-69.

Pope, C., Johnson, C., McRae, M., Keller, G. and Dresser, B. (1995): In vitro and in vivo development in cat oocytes following intracytoplasmic sperm injection or subzonal insemination. Theriogenology 43, 302.

Rátky, J., Brüssow, K., Solti, L., Torner, H. and Sarlós, P. (2000): Ovarian response, embryo recovery and results of embryo transfer in a Hungarian native pig breed. Theriogenology (accepted for publication).

Raven, R., Beese, K., Eisner, T., Morin, N., Duncan, T., Hobbs, S., Hodges, J., Rall, W., Colwell, R. and Swings, J. (1992): Biotechnology and genetic resources: United States - Commission of the European Communities Workshop, October 21-22, Airlie, Virginia, USA.

Reichenbach, H., Wiebke, N., Modl, J., Zhu, J. and Brem, G. (1994): Laparoscopy through the vaginal fornix of cows for the repeated aspiration of follicular oocytes. Vet. Rec. 135, 353-356.

Schiewe, M. C. (1991): Species variation in semen cryopreservation of nondomestic ungulates. Proc. Wild Cattle Symposium, Omaha, pp. 56-64. 
Schiewe, M. C., Bush, M., Phillips, L., Citino, S. and Wildt, D. (1991a): Comparative aspects of estrus synchronization, ovulation induction and embryo cryopreservation in the scimitarhorned oryx, bongo, eland and greater kudu. J. Exp. Zool. 58, 75-88.

Schiewe, M. C., Bush, M., de Vos, V. and Wildt, D. (1991b): Semen characteristics, sperm freezing and endocrine profiles in free-ranging wildebeest (Connochaetes taurinus) and greater kudu (Tragelaphus strepsiceros). J. Zoo Wildlife Med. 22, 58-72.

Schiewe, M. C., Bush, M., Stuart, L. and Wildt, D. (1984): Laparoscopic embryo transfer in domestic sheep: Preliminary study. Theriogenology 22, 675-682.

Seidel, G. and Seidel, S. (1981): The Embryo Transfer Industry. In: Brackett, B., Seidel, G., Seidel, S. (eds) New Technologies in Animal Breeding. Academic Press, New York, pp. 41-77.

Shaw, D., Kidson, A., Van Schalkwyk, J., Bartels, P., Loskutoff, N. M., Bezuidenhout, C., Barry, D. and Lishman, A. (1995): In vitro production of African buffalo (Syncerus caffer) embryos derived from follicular oocytes and epididymal sperm. Theriogenology 43, 322.

Solti, L., Macháty, Z., Bárándi, Zs., Török, M. and Vajta, G. (1992): IVF embryos of known parental origin from the endangered Hungarian Grey cattle breed. Theriogenology 37, 301-162.

Solti, L., Crichton, E., Loskutoff, N. M. and Cseh, S. (2000): Economical and ecological importance of indigenous livestock and the application of assisted reproduction to their preservation. Theriogenology 53, 149.

Stover, J., Evans, J. and Dolensek, E. (1981): Inter-species embryo transfer from the gaur to domestic Holstein. Proc. Amer. Assoc. Zoo Vet. pp. 122-124.

Summers, P., Shephard, A., Hodges, J., Kydd, J., Boyle, M. and Allen, W. (1987): Successful transfer of the embryo of Przewalski's horse (Equus przewalskii) and Grant's zebra (E. burchelli) to domestic mares (E. caballus). J. Reprod. Fert. 80, 13-20.

Uehara, T. and Yanagimachi, R. (1976): Microsurgical injection of spermatozoa into hamster eggs with subsequent transformation of sperm nuclei into male pronuclei. Biol. Reprod. 15, 467-474.

Wakayama, T. and Yanagimachi, R. (1998): Development of normal mice from oocytes injected with freeze-dried spermatozoa. Nat. Biotechnol. 16, 639-642.

Wells, D., Misica, P., Forsyth, J., Berg, M., Lange, J., Tervit, H. and Vivanco, H. (1999): The use of adult somatic cell nuclear transfer to preserve the last surviving cow of the Enderby Island cattle breed. Theriogenology 51, 217.

Wildt, D. (1991): The role of reproductive biotechnology in wildlife conservation: Problems and challenges. Proc. Soc. Study Theriogenology. pp. 15-22.

Wildt, D., Seal, U. and Rall, W. (1992a): Genetic resource banks and reproductive technology for wildlife conservation. In: Cloud, J. and Thorgaard, G. (eds) Genetic Conservation of Salmonid Fishes. Plenum Publishing Corp., New York, pp. 85-104.

Wildt, D., Monfort, S., Donoghue, A., Johnston, L. and Howard, J. (1992b): Embryogenesis in conservation biology - or, how to make an endangered species embryo. Theriogenology 37, 161-184.

Wilmut, I., Schnieke, A., McWhir, J., Kind, A. and Campbell, K. (1997): Viable offspring derived from fetal and adult mammalian cells. Nature 385, 810-813.

Yanagimachi, R. (1998): Intracytoplasmic sperm injection experiments using the mouse as a model. Hum. Reprod. 13 (Suppl 1), 87-95. 